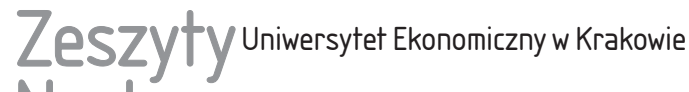 Naukowe
}

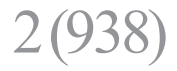

ISSN 1898-6447

Zesz. Nauk. UEK, 2015; 2 (938): 31-43 DOI: 10.15678/ZNUEK.2015.0938.0203

Krzysztof Jackowicz

Katedra Bankowości i Ubezpieczeń

Akademia Leona Koźmińskiego

Pawet Mielcarz

Katedra Finansów

Akademia Leona Koźmińskiego

\section{Inwestycje a wyniki finansowe przedsiębiorstw w okresie kryzysu}

\section{Streszczenie}

W artykule analizowany jest wpływ inwestycji dokonanych w latach dobrej koniunktury gospodarczej (2005-2007) na wyniki finansowe osiągnięte przez przedsiębiorstwa giełdowe okresie kryzysowym (2009-2011). Wykorzystując narzędzia długookresowej analizy zdarzeń, autorzy ustalili, że w całej próbie efekty kosztowe inwestycji były silniejsze niż korzyści płynące z modernizacji procesu produkcyjnego. W konsekwencji duża skala inwestycji przed kryzysem na ogół przyczyniała się do odnotowania gorszej rentowności w okresie kryzysu. Od tej zasady występowały jednak wyjątki branżowe.

Słowa kluczowe: inwestycje, kryzys, wyniki finansowe spółek giełdowych, rynki rozwijające się.

\section{Wprowadzenie}

Historia gospodarcza pokazuje, że kryzysy finansowe wywierają poważny wpływ także na przedsiębiorstwa działające w realnej sferze gospodarki. Ostatni kryzys nie był wyjątkiem od tej zasady. Potwierdzają to badania empiryczne przeprowadzone w ostatnich latach. Przykładowo, S. Akbar, S.U. Rehman i P. Ormrod [2013, s. 59-70] ustalili, posługując się próbą 5 tys. brytyjskich przed- 
siębiorstw i obserwacjami zgromadzonymi dla lat 2004-2009, że kryzys zrodzony w systemie finansowym negatywnie wpłynął na stopień wykorzystania dźwigni finansowej, głównie przez ograniczenie dostępności krótkoterminowych kapitałów obcych, zwiększył skłonność do utrzymywania wysokich sald gotówkowych, a ponadto odbił się niekorzystnie na rentowności aktywów i skali dokonywanych inwestycji. Do podobnych wniosków doszli A. Jalilvand i S.M. Kim [2013, s. 38-52], którzy badali przedsiębiorstwa z rynku amerykańskiego w okresie 1990-2011. Stwierdzili oni bowiem, że zarówno w okresie pęknięcia bańki spekulacyjnej związanej z akcjami tzw. dot.comów, jak i po załamaniu rynku kredytów typu sub-prime malały inwestycje przedsiębiorstw niefinansowych oraz powiększały się ich zapasy gotówki i płynnych aktywów. Zaprezentowane w niniejszym opracowaniu badanie wpisuje się w nurt rozważań dotyczących skutków kryzysu finansowego dla przedsiębiorstw produkcyjnych i usługowych. Cechuje je jednak specyficzna perspektywa interakcji oddziaływań kryzysowych i programów inwestycyjnych przedsiębiorstw prowadzonych przed okresem kryzysowym.

$\mathrm{Z}$ teoretycznego punktu widzenia nie jest jasne, czy inwestycje dokonane w okresie przed kryzysem zwiększają, czy też zmniejszają szanse przedsiębiorstw na umiejętne przeciwdziałanie jego skutkom. $Z$ jednej strony bowiem inwestycje umożliwiają zwiększenie mocy produkcyjnych, obniżenie kosztów jednostkowych, unowocześnienie produktów, podniesienie ich walorów użytkowych oraz często pozwalają na bardziej elastyczne reagowanie na wyzwania płynące z otoczenia. Dla ułatwienia można nazwać ten efekt modernizacyjnym. $Z$ drugiej strony realizacja inwestycji wiąże się z reguły ze wzrostem zadłużenia, kosztów finansowych i odpisów amortyzacyjnych. W konsekwencji pojawiają się czynniki oddziałujące w kierunku zmniejszenia wartości wskaźników bieżącej rentowności. Drugi opisany efekt można opatrzyć nazwą efektu kosztowego. W opracowaniu podejmujemy próbę empirycznego określenia, który z efektów: modernizacyjny czy kosztowy był silniejszy w Polsce w okresie spowolnienia gospodarczego. W tym celu przeprowadziliśmy długoterminową analizę zdarzeń, zgodną z metodyką zaproponowaną w pracy [Boubakri, Cosset i Saffar 2012, s. 397-423], bazującą na danych z lat 2005-2011 o spółkach notowanych na Giełdzie Papierów Wartościowych w Warszawie (GPW). Uzyskane wyniki wskazują, że, ogólnie rzecz biorąc, silniejszy był efekt kosztowy, ale od tej reguły występowały jednak odstępstwa branżowe.

W drugim punkcie prezentowanego artykułu dokonujemy krótkiego przeglądu literatury przedmiotu dotyczącej związków inwestycji i wyników działalności przedsiębiorstw, w punkcie trzecim stawiamy hipotezy badawcze, a następnie w punkcie czwartym charakteryzujemy konstrukcję użytych modeli ekonometrycznych i opisujemy zestaw danych. W piątym punkcie artykułu prezentujemy wyniki empiryczne wraz z ich interpretacją, a w szóstym podsumowujemy najważniejsze ustalenia. 


\section{Krótki przegląd literatury przedmiotu}

Związek inwestycji dokonywanych przez przedsiębiorstwa z osiąganymi przez nie wynikami finansowymi był przedmiotem setek analiz. W prezentowanym, krótkim opracowaniu nie jesteśmy w stanie dać pełnego przeglądu dorobku literatury przedmiotu. Dlatego skupimy się z jednej strony na ustaleniach empirycznych z ostatnich 20 lat, z drugiej zaś - na wynikach badań, które mają szczególne znaczenie dla testowanych w artykule hipotez.

W ostatnich latach najczęściej badano oddziaływanie na rezultaty gospodarowania przedsiębiorstw inwestycji w zakresie tzw. wysokich technologii, w tym informacyjnych oraz inwestycji w badania i rozwój. Przykładowo, wpływem inwestycji w sferze rozwiązań informatycznych zajmowali się H. Kivjärvi i T. Saarinen [1995, s. 143-163] w przypadku największych fińskich przedsiębiorstw, oraz J.K. Kim, J.Y. Xiang i S. Lee [2009, s. 678-687] na podstawie danych o chińskich przedsiębiorstwach z branży elektronicznej. Inwestycjami związanymi z działalnością badawczo-rozwojową interesowali się z kolei: I.H. Lee i M.R. Marvel [2009, s. 316-326], którzy dysponowali danymi o ponad 2,5 tys. małych i średnich przedsiębiorstw z Korei Południowej, I.C. Ehie i K. Olibe [2010, s. 127-135], którzy wykorzystali zestaw 26499 obserwacji o amerykańskich przedsiębiorstwach z okresu 1990-2007, oraz E. Pantagakis, D. Terzakis i S. Arvantis [2012], którzy posłużyli się stosunkowo skromną próbą 39 przedsiębiorstw z 17 krajów europejskich. Finansowe skutki wydatków związanych z zakupem technologii starali się określić K.-P. Hung i C. Chou [2013, s. 62-70] przy użyciu danych o 176 tajwańskich przedsiębiorstwach wytwórczych działających w branżach wysokich technologii, zaś skutki inwestycji w sferze szeroko rozumianych innowacji D.F.L. Santos i in. [2014, s. 527-535] na bazie dużej próby brazylijskich przedsiębiorstw. Dociekania nad konsekwencjami innych rodzajów inwestycji, zwłaszcza tych tradycyjnych, powiększających rzeczowe aktywa trwałe, pojawiały się rzadziej. Do tego nurtu należą przykładowo prace [Ghosal i Nair-Reichert 2009, s. 536-537] oraz [Hung, Yen i Ou 2012, s. 363-380]. Pierwsza z nich dotyczy inwestycji modernizacyjnych dokonanych przez 19 przedsiębiorstw celulozowo-papierniczych z różnych krajów w latach 1996-2003, druga odnosi się do zakupu urządzeń służących samoobsłudze klientów przez banki z Tajwanu. Specyficzną grupę opracowań stanowią te rozpatrujące związek inwestycji z wynikami przedsiębiorstw w kontekście działalności firm typu venture-capital [Rosenbusch, Brinckmann i Müller 2013, s. 335-353; Guo i Jiang 2013, s. 375-395].

Wymowa wspomnianych powyżej prac jest niejednoznaczna, co utrudnia dokonywanie uogólnień. Pozytywny lub przynajmniej częściowo pozytywny wpływ inwestycji na rezultaty gospodarowania przedsiębiorstw zidentyfikowali m.in. H. Kivjärvi i T. Saarinen [1995, s. 143-163], V. Ghosal i U. Nair-Reichert 
[2009, s. 536-537], I.C. Ehie i K. Olibe [2010, s. 127-135], D.H.-M. Wang [2010, s. 486-489], E. Pantagakis, D. Terzakis i S. Arvantis [2012] oraz K.-P. Hung i C. Chou [2013, s. 363-380]. W wielu analizach nie udało się jednak stwierdzić występowania statystycznie istotnej zależności wyników finansowych i nakładów inwestycyjnych lub oddziaływanie na wyniki okazywało się przynajmniej w wybranych aspektach negatywne. Jako przykłady mogą tu posłużyć dociekania: D.F.L. Santosa i in. [2014, s. 527-535], I.H. Lee i M.R. Marvela [2009, s. 316-326] oraz J.K. Kima, J.Y. Xianga i S. Lee [2009, s. 678-687]. W ostatnim przypadku zaproponowana interpretacja wyników badania odbiega od tej przedstawionej przez samych jego autorów, którzy konkludują, że inwestycje dodatnio wpływają na wyniki przedsiębiorstw. Wniosek ten w naszej ocenie jest jednak nieuzasadniony. Oszacowane w pracy [Kim, Xiang i Lee 2009, s. 678-687] modele regresji pokazują, że inwestycje oddziałują pozytywnie i statystycznie istotnie na poziomie 0,1 tylko na wskaźnik rentowności sprzedaży. Podobnej zależności J.K. Kim, J.Y. Xiang i S. Lee [2009, s. 678-687] nie stwierdzili ani dla zmiennych zależnych postaci wskaźników rentowności aktywów i kapitałów własnych, ani też dla stopy wzrostu sprzedaży i wskaźnika zysku na akcję.

Ważną cechą dorobku autorów zajmujących się omawianym zagadnieniem jest to, że identyfikują oni szereg czynników moderujących wpływ inwestycji na wyniki finansowe przedsiębiorstw. Należą do nich: współistnienie pewnych rodzajów inwestycji, branża działalności, okres analizy, skala nakładów inwestycyjnych, warunki panujące w otoczeniu i kraj pochodzenia obserwacji. I tak, K.-P. Hung i C. Chou [2013, s. 62-70] demonstrują, że pozytywne oddziaływanie inwestycji na rezultaty działania przedsiębiorstw jest szczególnie dobrze widoczne, gdy istnieją możliwości absorpcji nowych rozwiązań, na przykład gdy zakupom technologii towarzyszą wysokie wydatki wewnętrzne na badania i rozwój. I.C. Ehie i K. Olibe [2010, s. 363-380] dowodzą, że oddziaływanie inwestycji w danym okresie w sektorze przedsiębiorstw produkcyjnych może odbiegać od tego obserwowanego w sektorze usług. Z koleim H. Kivjärvi i T. Saarinen [1995, s. 143-163] pokazują, że pozytywny wpływ inwestycji na wyniki finansowe jest obserwowany głównie w długim okresie, prawdopodobnie z uwagi na konieczność uczenia się organizacji pełnego wykorzystania nowych możliwości. I.H. Lee i M.R. Marvel [2009, s. 316-326] ustalili zaś, że zależność wyników i inwestycji nie ma charakteru liniowego. W analizowanej przez nich próbie rezultaty gospodarowania były powiązane pozytywnie z intensywnością inwestycji przy ich niskich i wysokich poziomach oraz negatywnie przy średnich wartościach wskaźników obrazujących wielkość inwestycji. K.-P. Hung i C. Chou [2013, s. 62-70] stwierdzili, że wpływ inwestycji na wyniki był bardziej korzystny, gdy otoczenie rynkowe i technologiczne charakteryzowało się wysoką zmiennością, a I.C. Ehie i K. Olibe [2010, s. 127-135] dostarczyli pewnych dowodów na to, że ogólna sytuacja gospodarcza 
i polityczna mogą modyfikować charakter oddziaływania inwestycji na wyniki finansowe przedsiębiorstw. Natomiast D.H.-M. Wang [2010, s. 486-489] odkrył, że ten sam rodzaj inwestycji może wpływać pozytywnie na wyniki finansowe w jednym kraju, a nie mieć znaczenia w innym kraju z tego samego regionu.

Wśród wielu prac traktujących o wpływie inwestycji na wyniki finansowe przedsiębiorstw nie odnaleźliśmy analiz traktujących wprost o interakcjach inwestycji i rezultatów gospodarowania w warunkach kryzysowych. Oznacza to, że prezentowany krótki artykuł wypełnia lukę w dotychczasowym dorobku literatury przedmiotu.

\section{Hipotezy badawcze}

Jak wspomnieliśmy we wprowadzeniu, inwestycje dokonywane w okresie przed kryzysem mogą wpływać zarówno na podniesienie, jak i na zmniejszenie rentowności działania. Możliwość wystąpienia dodatniego, jak też negatywnego wpływu na wyniki działalności uprawdopodabnia także niejednoznaczna wymowa dorobku literatury przedmiotu. Przeciwstawne oddziaływania efektów kosztowego i modernizacyjnego oraz ich związek z hipotezami badawczymi ilustruje rys. 1. Jeśli korzyści wynikające z unowocześnienia parku maszynowego i produktów, zwiększenia możliwości elastycznego reagowania są większe niż wzrost kosztów, czyli efekt modernizacyjny jest silniejszy niż kosztowy, prawdziwa będzie hipoteza H1: Inwestycje dokonane przed polskie przedsiębiorstwa w okresie przedkryzysowym pozwoliły im osiągać lepsze wyniki finansowe w okresie kryzysu.

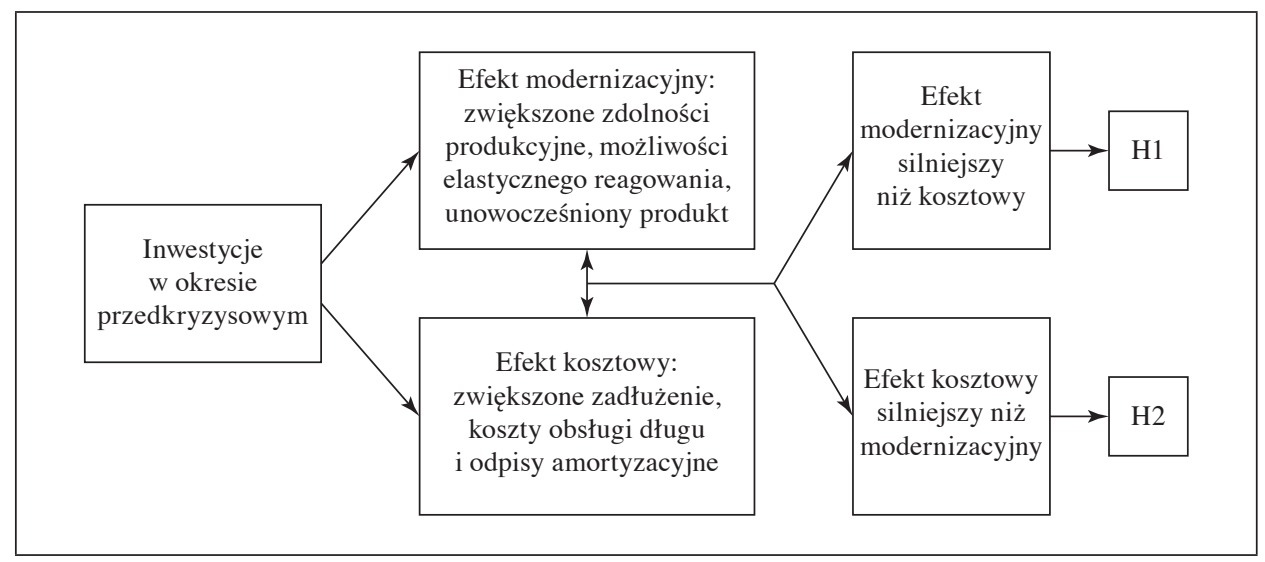

Rys. 1. Efekt modernizacyjny i kosztowy inwestycji a hipotezy badawcze Źródło: opracowanie własne. 
W przeciwnym wypadku - dominacji efektu kosztowego, tj. wtedy, gdy przedsiębiorstwa odczuły głównie negatywny wpływ wzrostu obciążeń z tytułu obsługi długu finansującego programy inwestycyjne, prawdziwa będzie hipoteza H2: Inwestycje dokonane przez polskie przedsiębiorstwa w okresie przedkryzysowym powiększają koszty i pogarszają wyniki finansowe w okresie kryzysu.

Na warszawskiej GPW notowane są przedsiębiorstwa z wielu branż. Ponadto, jak pokazali I.C. Ehie i K. Olibe [2010, s. 127-135], efekty inwestycji mogą być zróżnicowane w zależności od sektora działalności analizowanych podmiotów. Dlatego sformułowaliśmy hipotezę H3 i przetestowaliśmy, czy relatywna siła efektów: modernizacyjnego i kosztowego zależy od specyfiki branżowej: Wpływ inwestycji dokonanych przez polskie przedsiębiorstwa w okresie przedkryzysowym na późniejsze wyniki finansowe zależy od specyfiki branżowej.

\section{Konstrukcja modeli i zestaw danych}

W celu zweryfikowania postawionych hipotez przeprowadziliśmy długoterminowe badanie zdarzeń zgodnie z metodą zaproponowaną w pracy [Boubakri, Cosset i Saffar 2012, s. 397-423]. Podejście to pozwala analizować wpływ określonego czynnika na zmianę wybranych kategorii finansowych u podmiotów z próby. W badaniu sprawdziliśmy, w jaki sposób skala dokonywanych przez przedsiębiorstwa inwestycji w okresie dobrej koniunktury gospodarczej (20052007) przekłada się na zmianę rentowności niefinansowych spółek notowanych na GPW w Warszawie w czasie spowolnienia gospodarczego (2009-2011). Przyjęliśmy, że 2008 r. oddziela okres dobrej koniunktury od czasu spowolnienia gospodarczego. W literaturze traktującej o wpływie inwestycji na wyniki działalności przedsiębiorstw te ostatnie najczęściej mierzone są za pomocą księgowych wskaźników rentowności (np. [Kivjärvi i Saarinen 1995, s. 143-163; Lee i Marvel 2009, s. 316-326; Wang 2010, s. 486-489; Santos i in. 2014, s. 527-535]). Rzadziej wykorzystywane są mierniki rezultatów gospodarowania bazujące na rynkowej wycenie kapitału własnego (np. [Hung i Chou 2013, s. 363-380; Ehie i Olibe 2010, s. 127-135; Pantagakis, Terzakis i Arvantis 2012]). Z uwagi na to, że nasze badanie dotyczy okresu kryzysowego, w którym obserwuje się nadreaktywność rynków i mimetyczne zachowania inwestorów, zdecydowaliśmy się użyć wskaźników księgowych w funkcji zmiennej zależnej. Zmiennymi objaśnianymi w naszym badaniu są zmiany średnich rentowności na poziomie wyniku finansowego brutto $\left(\triangle R O S \_G\right)$ oraz wyniku na sprzedaży $\left(\triangle R O S \_M\right)$. Ogólną konstrukcję modeli służących ustaleniu determinant zmian rentowności ilustruje równanie (1):

$$
Z M W_{i}=f\left(I N V_{i} ; \operatorname{CONTROL~}_{i} ; I_{i k} ; I N V_{i} \times I_{i k}\right) .
$$


Indeks dolny $i$ koduje podmioty wchodzące w skład próby badawczej, $k$ natomiast - przynależność branżową danej spółki. $Z M W$ jest zmianą wspomnianych powyżej wskaźników rentowności. Zmiany rentowności liczone są jako różnice pomiędzy średnimi ROS dla poszczególnych przedsiębiorstw w okresie 2009-2011 w stosunku do lat 2005-2007. IN $V_{i}$ oddaje skalę inwestycji spółek objętych badaniem w okresie dobrej koniunktury gospodarczej. Mierzona jest ona jako średni iloraz wartości nakładów inwestycyjnych ponoszonych przez przedsiębiorstwa w latach 2005-2007 oraz wartości aktywów tych podmiotów na koniec kolejnych lat. I jest zmienną binarną kodującą przynależność przedsiębiorstwa $i$ do branży $k$. W badaniu uwzględniliśmy następujące branże: budowalną $(B U D)$, deweloperską $(D E W)$, energetyczną (ENE), handlu detalicznego (HAN_D), handlu hurtowego $\left(H A N \_H\right)$, hotelowo-restauracyjną (HOT_RES), informatyczną (INF), chemiczną $(C H E)$, drzewno-papierniczą $\left(D R Z_{-} P A P\right)$, elektromaszynową $\left(E L E \_M A S\right)$, motoryzacyjną $(M O T)$, farmaceutyczną $(F A R)$, przemysł lekki $(L E K)$, wytwarzania materiałów budowlanych $\left(M_{-} B U D\right)$, paliwową $(P A L)$, metalową $(M E T)$, telekomunikacyjną (TEL), spożywczą (SPO), usługową (USL), media $(M E D)$ oraz pozostały przemysł (POZ). Iloczyn zmiennych $I N V_{i} \times I_{i k}$ odzwierciedla specyficzny wpływ inwestycji dokonywanych przez przedsiębiorstwo z danej branży. CONTROL $L_{i}$ reprezentuje zbiór zmiennych kontrolnych szacowanych na podstawie danych finansowych poszczególnych przedsiębiorstw za $2008 \mathrm{r}$. Zmienne te obejmują: udział rzeczowych aktywów trwałych w aktywach ogółem ( $\left.R A T \_A\right)$, udział zobowiązań długoterminowych w pasywach ogółem $\left(Z D_{-} P\right)$, logarytm naturalny wartości sprzedaży $\left(L N \_S\right)$ oraz wskaźnik obrotowości aktywów (WOA).

Na próbę badawczą złożyły się wszystkie niefinansowe przedsiębiorstwa notowane na GPW w Warszawie w latach 2005-2011. Łącznie zebrano dane dla 179 notowanych podmiotów. Skonsolidowane sprawozdania finansowe tych przedsiębiorstw pobrano z bazy danych Notoria.

\section{Wyniki empiryczne}

Wyniki estymacji modeli przedstawione w tabeli 1 wskazują, że intensywne działania inwestycyjne prowadzone przez część polskich przedsiębiorstw giełdowych w okresie dobrej koniunktury gospodarczej wpłynęły na ogół negatywnie na ich rentowność w czasie spowolnienia gospodarczego. Statystycznie istotny, negatywny wpływ inwestycji na zmianę rentowności można zaobserwować zarówno na poziomie wyniku finansowego brutto (model 1), jak i wyniku na sprzedaży (model 2). Parametry otrzymane dla zmiennej INV są w obu przypadkach ujemne i statystycznie istotne na poziomie 0,1 (model 1) oraz na poziomie 0,05 (model 2). Uzyskane wyniki weryfikują zatem negatywnie H1 w całej próbie 
i przemawiają na korzyść H2 wskazującej, że inwestycje realizowane w okresie koniunktury prowadziły do zwiększenia kosztów stałych i w konsekwencji do obniżenia rentowności w okresie spowolnienia gospodarczego. Wyniki badania mogą sugerować, że poczynione przez polskie przedsiębiorstwa nakłady w latach prosperity gospodarczej miały głównie charakter projektów rozwojowych, ukierunkowanych przede wszystkim na podnoszenie mocy produkcyjnych lub też na ekspansję w ramach dotychczasowego modelu działania [Mielcarz i Paszczyk 2013, s. 163-213]. Tego typu projekty nie przyczyniają się do powstania wartościowych opcji realnych, które zabezpieczałyby przedsiębiorstwa przed skutkami pogorszenia się sytuacji gospodarczej [Mielcarz 2007, s. 87-108].

Tabela 1. Wpływ inwestycji realizowanych w latach 2005-2007 na rentowność przedsiębiorstw w okresie kryzysu (2009-2011)

\begin{tabular}{|l|c|c|}
\hline \multicolumn{1}{|c|}{ Zmienne zależne } & Model 1 & Model 2 \\
\hline \multirow{2}{*}{ Stała } & $\Delta R O S \_G$ & $\Delta R O S \_M$ \\
\hline \multirow{2}{*}{$I N V$} & $-0,042$ & $-0,137$ \\
& $(0,675)$ & $(0,134)$ \\
\hline \multirow{2}{*}{$R A T_{-} A$} & $-0,241^{*}$ & $-0,228^{* *}$ \\
& $(0,056)$ & $(0,013)$ \\
\hline \multirow{2}{*}{$Z T_{-} P$} & $-0,024$ & 0,101 \\
& $(0,765)$ & $(0,174)$ \\
\hline \multirow{2}{*}{$L N_{-} S$} & 0,030 & $-0,010$ \\
& $(0,660)$ & $(0,904)$ \\
\hline \multirow{2}{*}{ WOA } & 0,002 & 0,000 \\
Liczba obserwacji & $(0,775)$ & $(1,000)$ \\
\hline$R^{2}$ & $0,030^{*}$ & $0,026^{*}$ \\
& $(0,080)$ & $(0,065)$ \\
\hline
\end{tabular}

Uwaga: oba modele zawierają zmienne binarne kodujące przynależność branżową badanych przedsiębiorstw $(I)$, tzw. p-value oszacowane na bazie heteroskedastycznie zgodnych błędów oszacowania (HCSE) zostały przedstawione w nawiasach; ***,** oraz * wskazują na istotność statystyczną na poziomie odpowiednio: $0,01,0,05$ oraz 0,1 .

Źródło: opracowanie własne.

W celu weryfikacji hipotezy H3 oszacowaliśmy modele uwzględniające iloczyny zmiennych kodujących przynależność branżową spółek objętych badaniem oraz odzwierciedlających skalę podejmowanych przez nie inwestycji $(I N V \times I)$. Tabela 2 przedstawia wyniki badania w zakresie wpływu specyfiki branżowej na zmianę rentowności na poziomie wyniku ze sprzedaży, tabela 3 


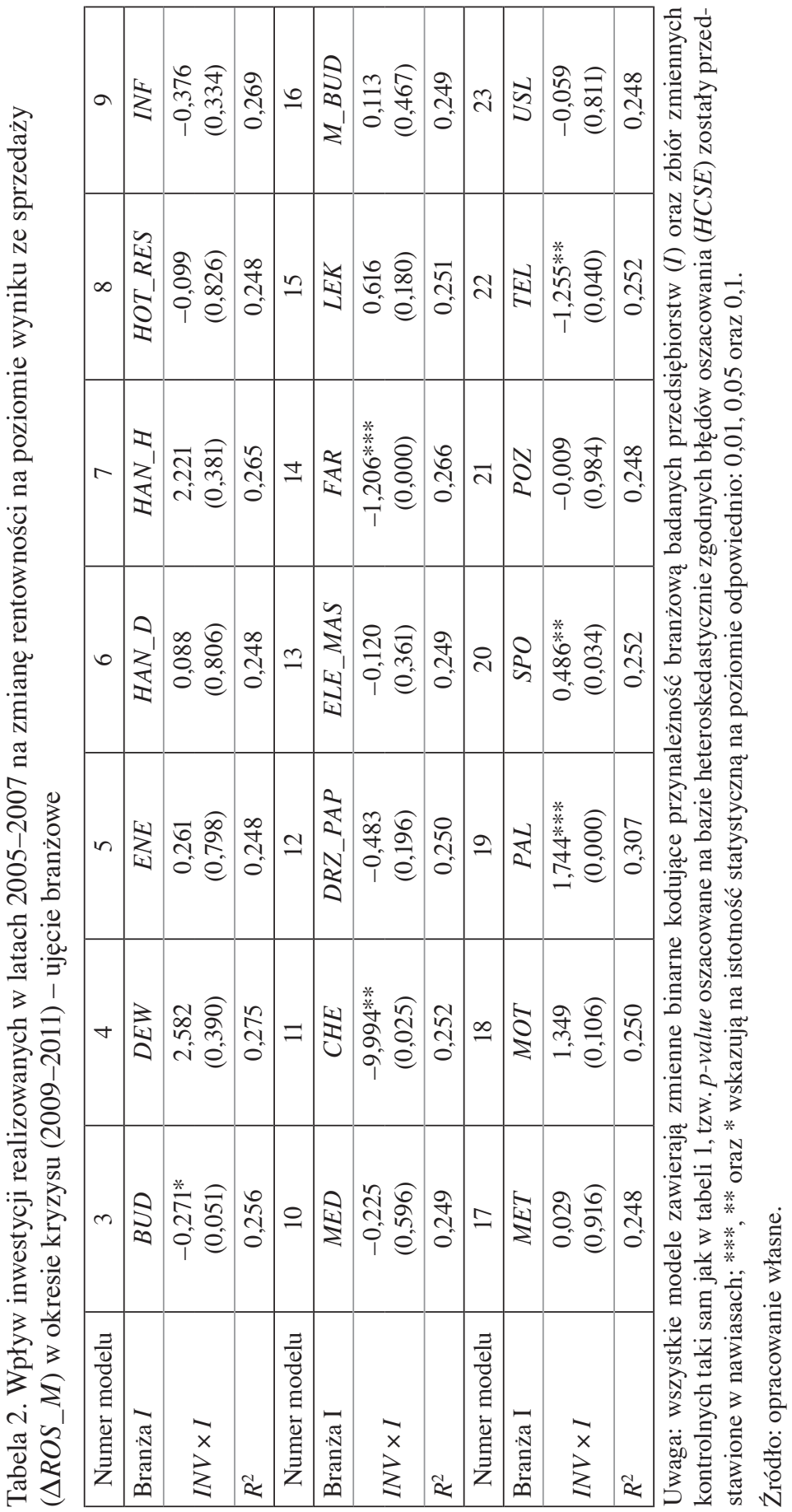




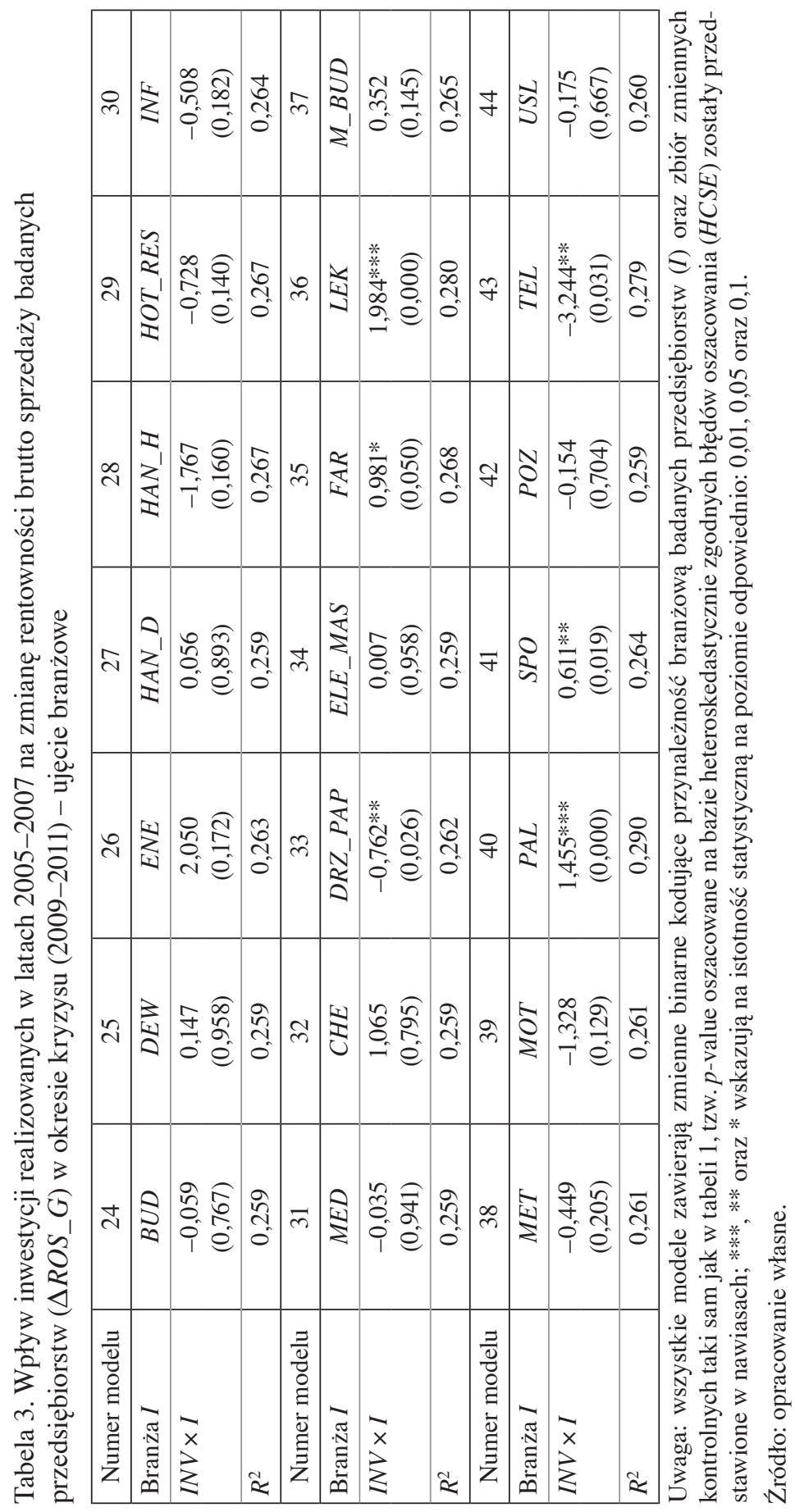


prezentuje natomiast rezultaty oszacowania modeli, w których zmienną zależną była zmiana rentowności na poziomie wyniku finansowego brutto.

Otrzymane rezultaty przemawiają na korzyść hipotezy H3. Od ogólnej zasady negatywnego wpływu inwestycji przed kryzysem na zmiany rentowności istnieją bowiem odstępstwa branżowe. I tak, przeprowadzone przed kryzysem inwestycje w branży paliowej $(P A L)$ i spożywczej $(S P O)$ wpłynęły pozytywnie na zmianę rentowności w okresie po 2008 r. Zależność tę widać na poziomie rentowności sprzedaży (modele 19 oraz 20), jak też w przypadku rentowności na poziomie wyniku finansowego brutto (modele 40 i 41). Jednoznacznie negatywny wpływ inwestycji na zmiany rentowności na poziomie wyniku ze sprzedaży i wyniku finansowego brutto stwierdziliśmy w przypadku branży telekomunikacyjnej (TEL, modele 22 i 43). Trudno jednak określić, na ile obserwowane obniżenie rentowności jest skutkiem inwestycji niedostosowanych do warunków kryzysowych, a na ile - efektem zaostrzającej się walki konkurencyjnej w branży telekomunikacyjnej po 2008 r. W branży budowlanej (BUD), farmaceutycznej (FAR) oraz chemicznej $(C H E)$ inwestycje przyczyniły się do spadków rentowności, ale wyłącznie na poziomie zysku na sprzedaży (modele 3, 11 i 14), co może sugerować, że spółki $\mathrm{z}$ tych branż uzyskiwały dodatkowe przychody finansowe $\mathrm{z}$ wcześniej akumulowanych zysków lub też korzystały z dotacji podnoszących pozostałe przychody operacyjne. Duża skala inwestycji wpłynęła również w statystycznie istotny sposób negatywnie na zmianę rentowności na poziomie wyniku finansowego brutto w branży drzewnej i papierniczej (DRZ_PAP, model 33).

\section{Podsumowanie}

Problematyka wpływu inwestycji dokonywanych przed kryzysem na zdolność przedsiębiorstw do prowadzenia rentownej działalności w okresie spowolnienia gospodarczego nie znalazła do tej pory, naszym zdaniem, należnego jej miejsca w polskiej literaturze przedmiotu. Przedstawione badanie stanowi próbę przynajmniej częściowego wypełnienia istniejącej luki. Uzyskane wyniki sugerują, że okres dobrej koniunktury gospodarczej przekłada się na zbytni optymizm spółek publicznych przy podejmowaniu decyzji inwestycyjnych. W całej próbie inwestycje dokonane przed kryzysem negatywnie oddziaływały na rentowność po 2008 r. Pozwoliło to negatywnie zweryfikować hipotezę H1, a pozytywnie H2, a więc uznać, że w Polsce w latach 2009-2011 efekty kosztowe inwestycji były silniejsze od modernizacyjnych. Analiza uwzględniająca specyfikę branżową wskazuje jednak, że w niektórych branżach menedżerowie poczynili inwestycje przygotowujące spółki do pogarszających się warunków w otoczeniu. Dalsze badanie w zakresie wpływu inwestycji na wyniki finansowe w okresie kryzysu 
powinny się toczyć, w naszej ocenie, dwutorowo. Po pierwsze, warto byłoby wykorzystać bardziej szczegółowe informacje o różnych typach inwestycji podejmowanych przez przedsiębiorstwa. Po drugie, wskazane jest sprawdzenie, czy zależności między inwestycjami a wynikami nie mają charakteru dwukierunkowego, jak to sugerują wyniki niektórych wcześniejszych badań [Heshmati i Lööf 2008, s. 268-282].

\section{Literatura}

Akbar S., Rehman S.U., Ormrod P. [2013], The Impact of Recent Financial Shocks on the Financing and Investment Policies of UK Private Firms, „International Review of Financial Analysis", vol. 26, http://dx.doi.org/10.1016/j.irfa.2012.05.004.

Boubakri N., Cosset J.-C., Saffar W. [2012], The Impact of Political Connections on Firms' Operating Performance and Financing Decisions, „Journal of Financial Research", vol. 35(3), http://dx.doi.org/10.1111/j.1475-6803.2012.01322.x.

Ehie I.C., Olibe K. [2010], The Effect of R\&D Investment on Firm Value: An Examination of US Manufacturing and Service Industries, „International Journal of Production Economics", vol. 128, http://dx.doi.org/10.1016/j.jpe.2010.06.005.

Ghosal V., Nair-Reichert U. [2009], Investments in Modernization, Innovation and Gains in Productivity: Evidence from Firms in the Global Paper Industry, „Research Policy", vol. 38, http://dx.doi.org/10.1016/j.respol.2008.10.010.

Guo D., Jiang K. [2013], Venture Capital Investment and the Performance of Entrepreneurial Firms: Evidence from China, ,Journal of Corporate Finance”, vol. 22, http:// dx.doi.org/10.1016/j.corpfin.2013.07.001.

Heshmati A., Lööf H. [2008], Investment and Performance of Firms: Correlation or Causality? „Corporate Ownership and Control”, vol. 6(2).

Hung K.-P., Chou C. [2013], The Impact of Open Innovation on Firm Performance: The Moderating Effects of Internal R\&D and Environmental Turbulence, „Technovation”, vol. 33, http://dx.doi.org/10.1016/j.technovation.2013.06.006.

Hung C.S., Yen D.C., Ou C.S. [2012], An Empirical Study of the Relationship between a Self-service Technology Investment and Firm Financial Performance, ,, Journal of Engineering and Technology Management”, vol. 29, http://dx.doi.org/10.1016/j.jengtecman.2011.09.006.

Jalilvand A., Kim S.M. [2013], Matching Slack Resources and Investment Strategies to Achieve Long-term Performance: New Perspective on Corporate Adaptability, ,The Journal of Economic Asymmetries", vol. 10, http://dx.doi.org/10.1016/j.jeca.2013.10.001.

Kim J.K., Xiang J.Y., Lee S. [2009], The Impact of IT Investment on Firm Performance in China: An Empirical Investigation of the Chinese Electronics Industry, „Technological Forecasting and Social Change", vol. 76, http://dx.doi.org/10.1016/j.techfore.2008.03.008.

Kivjärvi H., Saarinen T. [1995], Investment in Information Systems and the Financial Performance of the Firm, „Information and Management”, vol. 28, http://dx.doi. org/10.1016/0378-7206(95)94022-5. 
Lee I.H., Marvel M.R. [2009], The Moderating Effects of Home Region Orientation on $R \& D$ Investment and International SME Performance: Lessons from Korea, ,European Management Journal”, vol. 27, http://dx.doi.org/10.1016/j.emj.2009.04.011.

Mielcarz P. [2007], Metodologiczne i aplikacyjne problemy wycena opcji realnych za pomocq algorytmów wyceny opcji finansowych, „Współczesna Ekonomia”, nr 1.

Mielcarz P., Paszczyk P. [2013], Analiza projektów inwestycyjnych w procesie tworzenia wartości przedsiębiorstwa, PWN, Warszawa.

Pantagakis E., Terzakis D., Arvantis S. [2012], R\&D Investment and Firm Performance: An Empirical Investigation of the High Technology Sector (Software and Hardware) in the E.U, Working Paper available at SSRN: http://ssrn.com/abstract=2178919.

Rosenbusch N., Brinckmann J., Müller V. [2013], Does Acquiring Venture Capital Pay off for the Funded Firms? A Meta-analysis on the Relationship between Venture Capital Investment and Funded Firm Financial Performance, ,Journal of Business Venturing", vol. 28, http://dx.doi.org/10.1016/j.jbusvent.2012.04.002.

Santos D.F.L., Basso L.F.C., Kimura H., Kayo E.K. [2014], Innovation Efforts and Performances of Brazilian Firms, ,Journal of Business Research”, vol. 67(4), http://dx.doi. org/10.1016/j.jbusres.2013.11.009.

Wang D.H.-M. [2010], Corporate Investment, Financing, and Dividend Policies in the High-tech Industry, ,Journal of Business Research”, vol. 63, http://dx.doi.org/10.1016/ j.jbusres.2009.04.006.

\section{The Impact of Investment on Operational Performance during the Recent Crisis}

The article investigates how investments made during the pre-crisis period from 2005 to 2007 influenced the financial performance of listed firms in Poland during the crisis. Using long-term event study methodology, we established that the investments had a negative impact on operational performance as the cost effects of investment were stronger than the effects of modernising the production process. However, there were industry-specific exceptions to this rule.

Keywords: investment, crisis, financial performance of listed firms, emerging markets. 